\title{
MENINGKATKAN MOTIVASI KINERJA GURU MELALUI PENDEKATAN TRANSFORMASI DI SD ROYAL WELLS PRIMARY SCHOOL
}

\author{
SITI SARSAH \\ SD Royal Wells Primary School, Kota Bekasi, Jawa Barat \\ Email: sarsah06@gmail.com
}

\begin{abstract}
ABSTRAK
Penelitian ini bertujuan untuk meningkatkan motivasi kinerja guru melalui pendekatan transformasi di SD Royal Wells Primary School. Penelitian ini dilakukan pada semester ganjil tahun 2021/2022. Penelitian ini menitikberatkan pada kinerja guru dengan cara melakukan pengumpulan data melalui observasi, angket, dan mengumpulkan data kinerja. Waktu penelitian ada 2 siklus yaitu siklus 1 pada bulan Juli - September, sedangkan siklus 2 yaitu pada bulan Oktober - Desember. Objek penelitian yaitu guru SD Royal Wells Primary School. Kesimpulan dari penelitian ini adalah motivasi kerja guru meningkat dan didapati pengaruh yang positif sehingga profesionalitas guru sudah mulai bekerja secara maksimal, bersemangat, kreatif dan inovatif. Berdasarkan analisis data yang diperoleh dari supervisi berkas, program, absensi, supervisi kelas dan supervisi penilaian kinerja guru (PKG),telah terbukti, guru sudah mulai aktif dalam membuat administrasi pribadi tepat waktu dan pengelolaan kelas serta inovasi pembelajaran sudah bervariasi. Guru yang merupakan pendidikan profesional, mereka akan berkembang dengan pesat ketika pemimpinnya memberi teladan, peluang, memberi fasilitas, memotivasi , memberi pembinaan, dan membebaskan dalam berkreasi serta memberikan reward dan panisment yang jelas, maka motivasi yang diberikan kepala sekolah akan menghasilkan hasil yang signifikan yaitu terbukti dengan adanya peningkatan prosentase kehadiran. Dari siklus pertama sebanyak $93 \%$ meningkat ke siklus II sebanyak $100 \%$. Terdapat peningkatan sebanyak $6 \%$ dan dalam pengumpulan program dari $68 \%$ menjadi $91 \%$ terdapat peningkatan $19 \%$.
\end{abstract}

Kata kunci: Motivasi, Kinerja Guru, Pendekatan Transformasi

\begin{abstract}
This study aims to increase teacher performance motivation through a transformational approach at SD Royal Wells Primary School. This research was conducted in the first semester of 2021/2022. It focuses on teachers' performance by collecting data through observation, questionnaires, and collecting performance data. There are two research cycles, namely, 1 st cycle was in July - September, while 2nd cycle was in October - December 2021. The object of research is the teachers of Royal Wells Primary School. The conclusion of this study is that the work motivation of teachers increases and a positive influence is found so that the professionalism of teachers has started to work optimally, enthusiastically, creatively and innovatively. Based on the analysis of data obtained from file supervision, program, attendance, class supervision and teacher performance appraisal supervision (PKG), it has been proven that teachers have started to be active in making personal administration on time, class management and learning innovations have varied. Teachers who are professional educators, will develop rapidly when their leaders provide examples, opportunities, provide facilities, motivate, provide guidance, and liberate in being creative and provide clear rewards and punishments, then the motivation given by the principal will produce significant results, namely evidenced by an increase in the percentage of attendance. From the first cycle as much as $93 \%$ increased to the second cycle as much as $100 \%$. There was an increase of $6 \%$ and in program pooling from $68 \%$ to $93 \%$ there was an increase of $19 \%$.
\end{abstract}

Keywords: Motivation, Teacher Performance, Transformation Approach

\section{PENDAHULUAN}

Pendidikan mempunyai peran yang sangat penting dalam perkembangan dan kelangsungan hidup bangsa. Menurut Kamus Besar Bahasa Indonesia, pendidikan adalah 
proses pengubahan sikap dan tata laku seseorang atau kelompok orang dalam usaha mendewasakan manusia melalui upaya pengajaran dan pelatihan; proses, cara dan pembuatan mendidik. Sekolah sebagai tempat penyelenggara pendidikan di dalamnya terdapat struktur organisasi yang dipimpin oleh Kepala Sekolah, dan guru sebagai subyek pendidikan yang berhubungan langsung dengan siswa. Pelaksanaan fungsi dan tugas guru sebagai profesi tentu dituntut bekerja profesional dan maksimal. Sebagai pendidik dan pengajar, guru harus memiliki beberapa syarat, diantaranya penguasaan profesional keguruan, penguasaan materi pelajaran, kreatif, inovasi, penguasaan cara-cara menyesuaikan diri dan berkepribadian yang baik untuk melaksanakan tugas, serta guru harus dapat berkomunikasi dan dapat mentransfer ilmunya dengan baik ke siswa, agar ilmu yang disampaikan dapat dipahami dan dimengerti, sehingga tidak salah mengartikan maksudnya. Guru merupakan kunci dalam mengembangkan pendidikan.dan guru menjadi ujung tombak serta inovator dalam peningkatan mutu pendidikan.

Peningkatan mutu pendidikan merupakan suatu hal yang penting dalam proses pendidikan. Depdiknas (Hidayah, 2012) menyebutkan bahwa, mutu pendidikan mencakup input, proses dan output pendidikan. Mutu input dan proses mencakup bahan ajar, metodologi pembelajaran yang bervariasi sesuai dengan kemampuan guru, media pembelajaran yang tepat, sumber belajar yang lengkap, sistem penilaian dan evaluasi yang efektif, dukungan administrasi sekolah dan dukungan sarana prasarana. Mutu output/hasil pendidikan mengacu pada prestasi yang dicapai sekolah dalam kurun waktu tertentu, yang meliputi prestasi akademik dan non akademik.

Dalam Peraturan Menteri Pendidikan Nasional No.63 tahun 2009 tentang sistem penjaminan mutu pendidikan Pasal (1) ayat (1), bahwa mutu pendidikan adalah tingkat kecerdasan kehidupan bangsa yang dapat diraih dari penerapan Sistem Pendidikan Nasional. Kemendikbud (2014, hlm. 7) mendefinisikan bahwa mutu pendidikan di sekolah dasar adalah kemampuan sekolah dalam pengelolaan secara operasional dan efisiensi terhadap komponenkomponen yang berkaitan dengan sekolah, sehingga menghasilkan nilai tambah terhadap komponen tersebut menurut norma/standar yang berlaku (Suwartini, 2017)

Agar mutu pendidikan yang baik dapat tercapai, maka mutu tersebut harus didukung oleh sekolah yang bermutu. Sekolah yang bermutu adalah sekolah yang secara keseluruhan dapat memberikan kepuasan kepada masyarakat (Jodenmot, 2012) Pendapat ini cukup beralasan, karena terlalu banyak pengelolaan sekolah, yang mengabaikan kepuasan dan kebutuhan pelanggan, sehingga hasilnya pun akhirnya tidak mampu untuk berkompetisi guna meraih peluang dalam berbagai bidang, khususnya dalam menghadapi kondisi global dimana sekolah diharapkan dapat berperan lebih efektif dalam mengembangkan fungsinya. Sekolah unggul (excellent school) adalah sekolah yang memiliki manajemen sekolah dan berkarakteristik, menurut Sallis (Jodenmot, 2012) yakni: (1) guru memiliki kepemimpinan yang kuat dan kepala sekolah memberikan perhatian tinggi terhadap perbaikan mutu pengajaran, (2) guru memiliki kondisi pengharapan yang tinggi untuk mendukung pencapaian prestasi murid, (3) atmosfer sekolah tidak kaku, sejuk tanpa tekanan, kondusif dalam seluruh proses pengajaran, berlangsung dalam suatu keadaan/iklim yang nyaman, (4) sekolah memiliki pengertian yang luas tentang fokus pengajaran dan mengusahakan efektif sekolah dengan energi dan sumber daya untuk mencapai tujuan pengajaran secara maksimal, (5) sekolah efektif dalam menjamin kemajuan murid yang dimonitor secara periodik

Untuk meningkatkan mutu sekolah diperlukan dukungan kepemimpinan kepala sekolah dan manajemen sekolah. Menurut Salis (dalam Jodenmot, 2012), mengatakan bahwa keberhasilan sekolah dalam mencari tujuan instusional pendidikan bergantung pada profesionalitas kepala sekolah sebagai pemimpin pendidikan (education leader /school director). Kepala sekolah merupakan tumpuan manajemen sekolah. Manajemen sekolah bertujuan dan berupayamencapai tujuan institusi, karena kepala sekolah bertujuan dan memiliki kewengangan dalam menetapkan arah pendidikan sekolah melalui visi, misi, dan tujuan yang diharapkan akan mampu meningkatkan keberhasilan sekolah. Kolaborasi yang seimbang antara manajemen, kepala sekolah, guru, masyarakat, dan peserta didik akan menghasilkan sekolah 
yang berprestasi Kepemimpinan kepala sekolah tidak akan berjalan baik jika tidak adanya kerjasama antara kepala sekolah dan guru. Guru merupakan orang yang berhubungan langsung dengan peserta didik dan orang tua murid. Untuk itu seorang guru harus mampu menampilkan yang terbaik dalam menjalankan setiap aktivitas tugas dan pelayanannya. Kunci agar guru mau dan mampu menjalankan tugasnya secara optimal adalah adanya motivasi. Tingginya motivasi guru sangat dipengaruhi juga oleh gaya kepemimpinan kepala sekolah sebagai pemegang kendali. Menurut Ardianto, Ismanto (2012) Kepemimpinanan adalah kemampuan seseorang dalam memimpin, mengarahkan, mengendalikan baik orang-orang yang ada di kesatuannya ataupun fasilitas lain yang berbeda dalam wewenangnya sedangkan Wahyudi (2009:120) mengatakan Kepemimpinan dapat diartikan sebagai kemampuan seseorang dalam mengerakkan, mengarahkan, sekaligus mempengaruhi pola pikir, cara kerja setiap anggota agar bersikap mandiri dalam bekerja, terutama dalam pengambilan keputusan untuk kepentingan percepatan pencapaian tujuan yang telah ditetapkan. Kepala sekolah harus memilki visi, program, dan strategi dalam kepemimpinannya. Kepala Sekolah juga harus menjadi teladan, motivator, kreatif, dan inovator. Tidak hanya sampai membimbing, memonitor, membina, dan mengarahkan tetapi juga harus terus dipantau, disupervisi, diberi pembinaan baik dari dalam maupun dari luar, serta terus dilakukan tindak lanjut agar motivasi guru tetap terjaga dam berkembang.

Untuk meningkatkan motivasi guru, kepala sekolah dan guru dituntut keprofesionalannya dalam melaksanakan tugas pokok dan fungsinya. Motivasi juga tidak lepas dari kesadaran dari guru itu sendiri karena akan sia-sia motivasi dari Kepala sekolah dalam melaksanakan kepemimpinannya..Motivasi dapat dilakukan secara internal dan eksternal. Motivasi secara internal yaitu yaitu kemauan dari diri sendiri untuk berubah ,sedangkan motivasi secara eksternal yaitu upaya yang dilakukan Kepala Sekolah dalam meningkatkan mutu pendidikan. Motivasi secara internal dan eksternal harus seimbang karena bila tidak seimbang maka motivasi dariluar tidak akan berarti.

Kesadaran diri sendiri dalam menghargai dirinya dan orang lain adalah merupakan motivasi terbesar untuk memajukan prestasi dan kinerja diri. Berpikir maju, kreatif dan inovatif menjadi dasar untuk guru lebih berkembang dengan terus mencari hal yang lebih baik dalam kerjanya, sehingga motivasi kerjanya terus mengembang menjadi individu yang sukses. kinerja adalah suatu prestasi kerja atau hasil kerja seseorang berdasarkan kuantitas dan kualitas yang dicapainya dalam melaksanakan fungsinya sesuai dengan tanggung jawab yang diterima sehingga meningkatkan kinerja guru.

Untuk meningkatkan motivasi kerja guru, maka diperlukan pendekatan Transformasi. Menurut Burns (Riadi, 2017), Kepemimpinan transformasional dicirikan sebagai pemimpin yang berfokus pada pencapaian perubahan nilai-nilai, kepercayaan, sikap, perilaku, emosional, dan kebutuhan bawahan menuju perubahan yang lebih baik di masa depan dan menurut pendapat dari Robbins dan Judge (Riadi, 2017), pemimpin transformasional adalah pemimpin yang menginspirasi para pengikutnya untuk menyampingkan kepentingan pribadi mereka, demi kebaikan organisasi dan mampu memiliki pengaruh yang luar biasa pada diri para pengikutnya

Permasalahan yang dihadapi seorang pemimpin, yaitu salah satunya Kepala Sekolah, dalam memimpin organisasinya adalah tidaklah mudah, diperlukan strategi yang tepat untuk meningkatkan kinerjanya teamnya. Berbagai strategi dilakukan agar lembaga yang dipimpinnya berkembang dengan baik, maka diperlukan kerjasama antara Kepala sekolah dan guru. Walaupun sudah memiliki strategi yang tepat tapi terkadang masih ditemukan kelemahan dalam menerapkan strateginya, untuk itu diperlukan pendekatan terhadap team yang dipimpinnya. Berdasarkan implimentasi di lapangan ditemukan (1) Partisipasi guru dalam menyampaikan ide dan saran kepada Kepala Sekolah belum maksimal (2)Masih ada guru yang belum kreatif dalam mengajar, (3) Komunikasi guru dengan Kepala Sekolah belum terjalin dengan baik, (4) Kedisiplinan guru di sekolah belum maksimal, (5) Motivasi dan Kinerja Guru kurang maksimal, (6) Masih ada guru yang kurang efektif dan efisien dalam penggunaan waktu, (7) Masih ada guru yang kurang menguasai teknologi. 
Implimentasi yang ditemukan di lapangan, maka diperlukan Kepala Sekolah yang mempunyai wawasan yang luas dan berpikir jauh ke depan. Kepala sekolah juga harus menemukan pendekatan dan memimpin yang tepat serta harus memiliki visi, strategi dan motivasi yang tinggi sehingga pemimpin akan berusaha untuk melakukan suatu perbaikan terhadap lembaga pendidikan yang dikelolanya, bukan untuk saat ini saja, akan tetapi sampai masa yang akan datang. Oleh karena itu, kepala sekolah dan lembaga pendidikan yang dipimpinnya dapat mengimplementasikan model kepemimpinan dalam mengelola lembaga sekolah yang dipimpinnya agar dapat melakukan perubahan sehingga lembaga sekolah yang dipimpinnya berkembang dengan pesat dan berkualitas karena memiliki sumber daya manusia yang sesuai harapan yaitu bertanggungjawab,kreatif, inovatif dan memiliki kepribadian yang baik.

Penelitian ini bertujuan untuk meningkatkan kinerja guru, mengetahui hambatan kepala sekolah dalam menerapkan strategi kepemimpinanannya, mengetahui kendala yang dihadapi guru, dan memperbaiki strategi kepemimpinan dalam upaya meningkatkan motivasi kinerja guru melalui pendeakatan transformasi.

Berdasarkan permasalahan tersebudi atast, peneliti tertarik untuk melakukan penelitian mengenai Upaya Meningkatkan Motivasi Kinerja Guru melalui Pendekatan transformasi di SDS Royal Wells Primary School.

\section{METODE PENELITIAN}

Penelitian ini dilakukan dengan metode penelitian tindakan sekolah yang berlangsung selama 2 siklus. Masing-masing siklus terdiri dari tahapan perencanaan, pelaksanaan, observasi dan refleksi. Metode penelitian yang dilakukan peneliti adalah dengan melaksanakan Penerapan Kepemimpinan Transformasi yang meliputi supervise tradisional dan supervise klinis.

Penelitian Tindakan Sekolah dilaksanakan di SDS Royal Wells Primary School. Jalan Puncak Cikunir no. 25 Kampung Dua, Jakasampurna, Bekasi Barat, Kota Bekasi, Jawa Barat. Adapun yang menjadi subjek penelitian adalah 17 orang Guru, Waktu pelaksanaan dilakukan pada semester ganjil dengan 2 kali siklus, yaitu siklus 1 dari bulan Juli sampai September dan siklus ke 2 pada bulan Oktober - Desember 2021. dengan penerapan Kepemimpinan Transformasi yang berkelanjutan diharapkan mampu meningkatkan motivasi guru.

Pada tahap perencanaan, peneliti merencanakan langkah-langkah sebagi berikut:

(1) Mengidentifikasi jumlah guru yang sudah melakasankan komponen administrasi kegiatan belajar mengajar;

(2) Meminta guru untuk membuat administrasi pribadi dan kelas;

(3) Peneliti memeriksa administrasi guru dan pola secara deskriptif kualitatif;

(4) Peneliti mengidentifikasi permasalahan yang ditemukan;

(5) Menyusun rencana tindakan (berupa penjadwalan supervisi individual atau kelompok disesuaikan dengan temuan pada identifikasi masalah)

\section{HASIL DAN PEMBAHASAN}

Pada tahap pelaksanaan, peneliti melaksanakan rencana tindakan supervisi individual, untuk menilai absensi dan administrasi guru. Pertama peneliti mempersiapkan perangkat penelitian berupa lembar presensi kehadiran, kelengkapan administrasi guru,dan penilaian kinerja guru, selain itu juga dipersiapkan lembar observasi, Penelitian dilaksanakan pada tanggal 25-30 September 2021 dengan jumlah guru sebanyak 17 orang. Pada tahap observasi, Kepala sekolah dibantu salah satu guruserta pengawas dinas, melakukan supervisi persensi dengan format yang ditetapkan oleh yayasan dan program kerja guru dengan format supervisi guru, hasil awal yang dicapai pada pelaksanaan tindakan siklus 1 , target pencapaian persentasi guru harus mencapai minimal 95\% dari $100 \%$ dan berdasarkan pengumpulan program harus minimal 90\% dari 100\%. Dari hasil penelitian ditemukan persentasi sebesar 93\% sedangkan untuk pengumpulan program guru masih $68 \%$. Selain itu peneliti juga mengidentifikasi 
masalah-masalah lanjutan yang timbul dari pelaksanaan tindakan di siklus 1. Pada tahap refleksi, peneliti melakukan evaluasi terhadap tindakan dan data-data yang diperoleh. Kemudian dilanjutkan dengan pertemuan bersama kolaborator untuk membahas hasil evaluasi dan penyusunan langkah-langkah untuk siklus kedua.

Pada tahap pelaksanaan Siklus 2, peneliti meningkatkan kinerja guru yaitu dengan menerapkan pendekatan transformasi dengan tetap melaksanakan rencana tindakan supervisi individual, untuk menilai presensi, administrasi guru, dan penilaian kinerja guru. Pada tahap ini peneliti mempersiapkan perangkat penelitian berupa lembar presensi kehadiran dan kelengkapan administrasi guru ditambahlkan dengan nilai PKG. Penelitian dilaksanakan pada bulan Oktober - Desember 2021 dengan jumlah guru sebanyak 17 orang dengan pendekatan transformasi maka terjadi peningkatan yang signifikan. Pada tahap observasi, Kepala sekolah dibantu salah satu guru, HRD, dan Pengawas dinas untuk melakukan supervisi persensi dengan format yang ditetapkan oleh yayasan, program kerja guru dengan format supervisi guru, dan Penilaian kinerja guru. Hasil yang didapat yaitu hasil presensi Guru dari 93\% menjadi 100\%, sedangkan Pengumpulan program dari 68\% menjadi 91\% dan Program penilaian guru (PKG) dibantu pihak kedinasan sebagai bentuk monitoring dan supervisi dari $72 \%$ menjadi $91 \%$ dengan kategori Baik

\section{Pembahasan}

\section{Siklus I}

\section{a. Tahap Perencanaan}

Pada tahap ini peneliti mempersiapkan perangkat penelitian berupa lembar presensi kehadiran dan pengumpulan program kerja guru. Selain itu juga dipersiapkan lembar observasi 1. Format Absen Juli - September

Tabel 1 Format Absen

\begin{tabular}{|c|c|c|c|c|}
\hline Nama & Date & Chek in & Chekout & Late \\
\hline & & & & \\
\hline & & & & \\
\hline & & & & \\
\hline & & & & \\
\hline dst & & & & \\
\hline
\end{tabular}

2. Format Program Kinerja Guru

Untuk mengetahui kinerja guru, kepala sekolah melakukan observasi melalui supervise berkas dan supervisi kelengkapan administrasi guru. Format yang digunakan yaitu format kedinasan, yang hasilnya ditandatangani ditandatangi oleh pengawas dan kepala sekolah. 


\section{Vol. 1 No. 3 Desember 2021, p-2797-5592 | e-2797-5606}

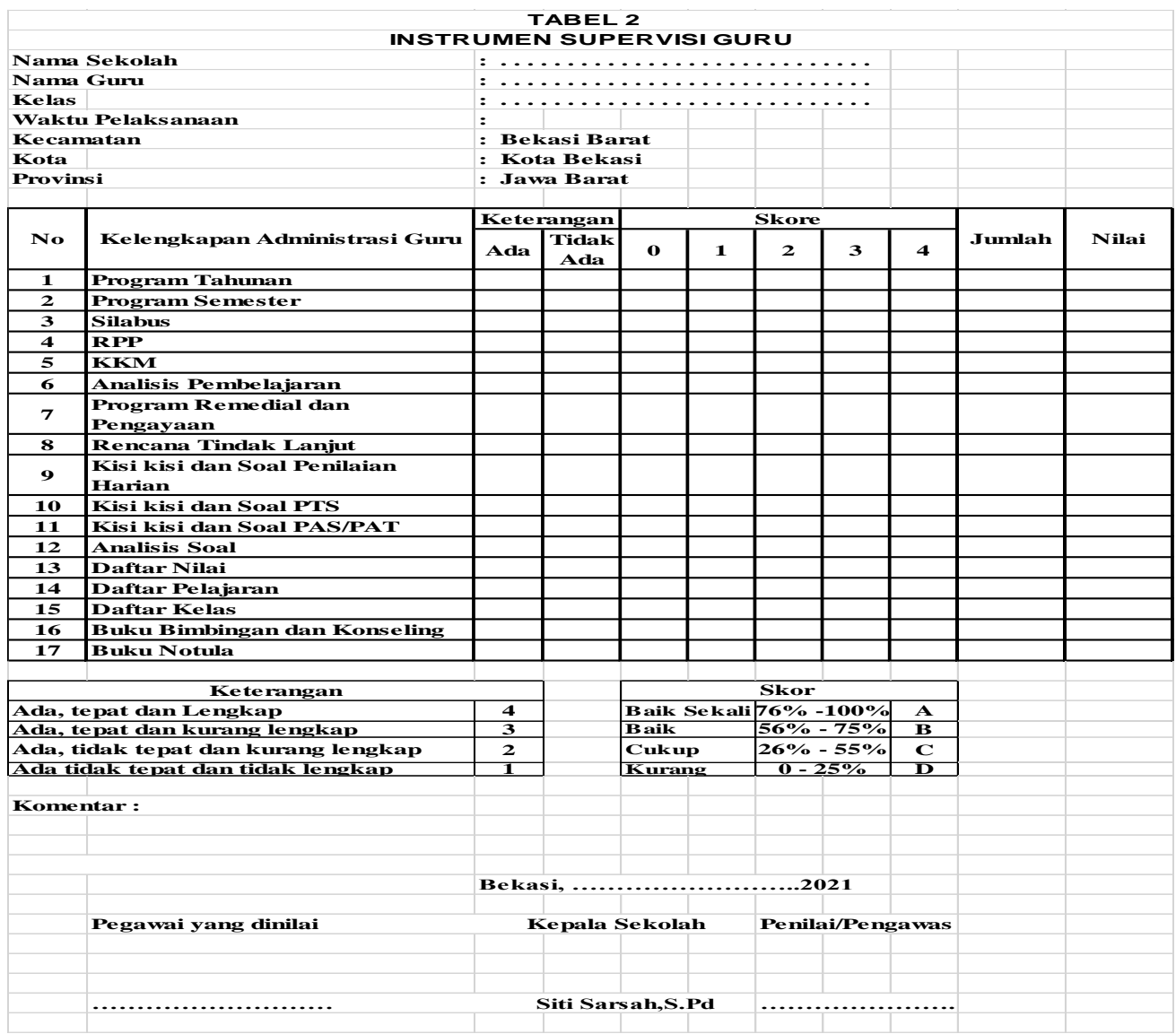

\section{Format Penilaian KInerja Guru}

Tabel 3

Perangkat Penilaian Kinerja Guru

\begin{tabular}{|c|c|c|c|c|c|}
\hline \multirow{2}{*}{ No } & \multirow{2}{*}{ Kompetensi } & \multicolumn{4}{|c|}{ Skor } \\
\hline & & 1 & 2 & 3 & 4 \\
\hline 1 & Menguasai karakteristik peserta didik & & & & \\
\hline 2 & Menguasai teori belajar dan prinsip-prinsip pembelajaran yang mendidik & & & & \\
\hline 3 & Pengembangan Kurikulum & & & & \\
\hline 4 & Kegiatan pembelajaran mendidik & & & & \\
\hline 5 & pePengembangan potensi anak didik & & & & \\
\hline 6 & Komunikasi dengan peserta didik & & & & \\
\hline 7 & Penilaian dan Evaluasi & & & & \\
\hline 8 & $\begin{array}{l}\text { Bertindak sesuai dengan norma agama, hukum, sosial, dan kebudayaan } \\
\text { nasional }\end{array}$ & & & & \\
\hline 9 & Menunjukan pribadi yang dewasa dan teladan & & & & \\
\hline 10 & Etos kerja, tanggungjawab yang tinggi, rasa banga menjadi guru & & & & \\
\hline 11 & Bersikap inklusif, bertindak obyektif, serta tidak diskriminatif & & & & \\
\hline 12 & $\begin{array}{l}\text { Komunikasi dengan sesama guru, tenaga kependiidkan, orang tua, } \\
\text { peserta didik, dan masyarakat }\end{array}$ & & & & \\
\hline 13 & $\begin{array}{l}\text { Penguasaan materi, struktur, konsep dan pola pikir keilmuan yang } \\
\text { mendukung mata pelajaran yang diampu }\end{array}$ & & & & \\
\hline 14 & Mengembangan keprefosionalan melalui tindakan reflektif & & & & \\
\hline & Jumlah ( hasil Kinerja Guru) & & & & \\
\hline $\begin{array}{l}\text { Konve } \\
\text { tahun }\end{array}$ & $\begin{array}{l}009 \text { dengan rumus } \\
009 \text { ilai PK Guru dalam skala } 0-100 \text { sesuai Permeneg PAN \& RB N0.16 }\end{array}$ & & & & \\
\hline Nilai I & $\begin{array}{lll}\mathrm{KG}(100)= & \text { Nilai PKG } & \mathrm{x} 100 \\
& \text { Nilai PKG tertinggi } \\
\end{array}$ & & & & \\
\hline $\begin{array}{l}\text { Berda } \\
\text { terseb }\end{array}$ & $\begin{array}{l}\text { arkan hasil konversi ke dalam skala nilai sesuai dengan peraturan } \\
\text { t. Selanjutnya ditetapkan sebutan dan persentase angka kredit }\end{array}$ & & & & \\
\hline
\end{tabular}




\section{b. Tahap Kegiatan dan Pelaksanaan}

Pelaksanaan kegiatan belajar mengajar untuk siklus I , dilaksanakan supervise pada tanggal 25-30 September 2021 dengan jumlah guru sebanyak 18 orang.

1. Mengumpulkan absen dari bulan Juli - September

Tabel 4. Rekapitulasi Penilaian Absen Periode Juli September

\begin{tabular}{|c|c|c|c|c|c|}
\hline No & Bulan & $\begin{array}{c}\text { Jumlah } \\
\text { Kehadiran }\end{array}$ & Kehadiran & Absensi (\%) & Ket \\
\hline & Juli & 180 & 180 & $100 \%$ & WFH \\
\hline & Agustus & 396 & 364 & $92 \%$ & WFH \\
\hline & September & 396 & 362 & $91 \%$ & Offline \\
\hline & Total & 972 & 906 & $93 \%$ & \\
\hline
\end{tabular}

2. Mengumpulkan nilai Program Guru bulan Juli samapai September

Tabel 5. Interval Program guru

\begin{tabular}{|c|c|c|}
\hline Interval & Nilai & Grade \\
\hline $3.6-4.0$ & 4 & A \\
\hline $2.6-3.5$ & 3 & B \\
\hline $1.6-2.6$ & 2 & C \\
\hline $1.0-1.5$ & 1 & D \\
\hline
\end{tabular}

Tabel 6. Rekapitulasi Penilaian Program Guru Periode Juli-September 2021

\begin{tabular}{|c|l|c|c|c|c|c|}
\hline No & Penilaian & Jumlah Guru & Interval & & Siklus 1 & $\%$ \\
\cline { 4 - 7 } & & & Tertinggi & Terendah & & \\
\hline 1 & Administrasi Kelas & 17 & 4 & 2 & 2,1 & $53 \%$ \\
\hline 2 & RPP & 17 & 4 & 2 & 2,9 & $73 \%$ \\
\hline 3 & Soal CA1/ UTS & 17 & 4 & 2 & 3 & $75 \%$ \\
\hline 4 & Kelengkapan Admin & 17 & 4 & 2 & 2,8 & $70 \%$ \\
\hline \multicolumn{2}{|c|}{ Total } & & & & 10,8 & $68 \%$ \\
\hline
\end{tabular}

\section{c. Pengamatan (observasi)}

Dilaksanakan bersamaan dengan pelaksanaan belajar mengajar. Sebagai pengamat adalah peneliti dibantu oleh seorang guru.

Dengan hasil penelitian sebagai berikut: Dari hasil penelitian terhadap 17 orang guru dapat disimpulkan bahwa: Jumlah yang seharusnya didapat dari persentasi guru harus mencapai minimal $95 \%$ dari $100 \%$ dan berdasarkan pengumpulan program harus minimal $90 \%$ dari $100 \%$. Dan ditemukan pada tahap observasi bahwa kinerja guru pada persentasi ditemukan 93\% sedangkan untuk pengumpulan program masih 68\%. Pada masa pandemic ini guru melakukan absensi berdasarkan absensi dalam metode pembelajaran online maupun offline dengan system absensi manual secara link dan pengumpulan program belajar secara online (PJJ) dalam bentuk pelaporan setiap minggu

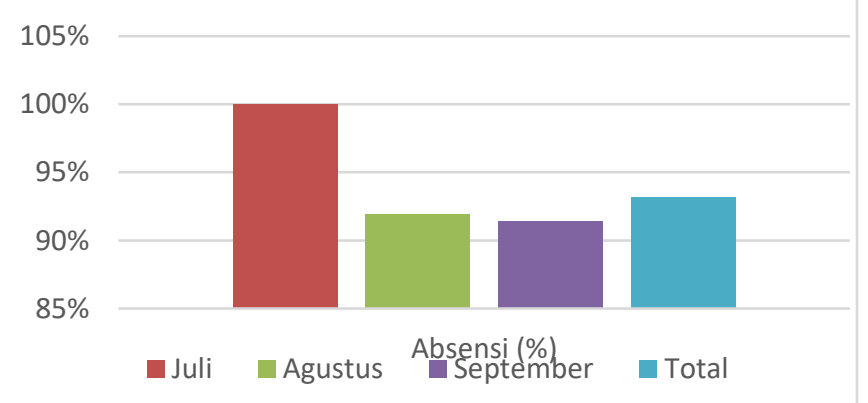

Gambar 1.Grafik Absensi Juli-September 2021 


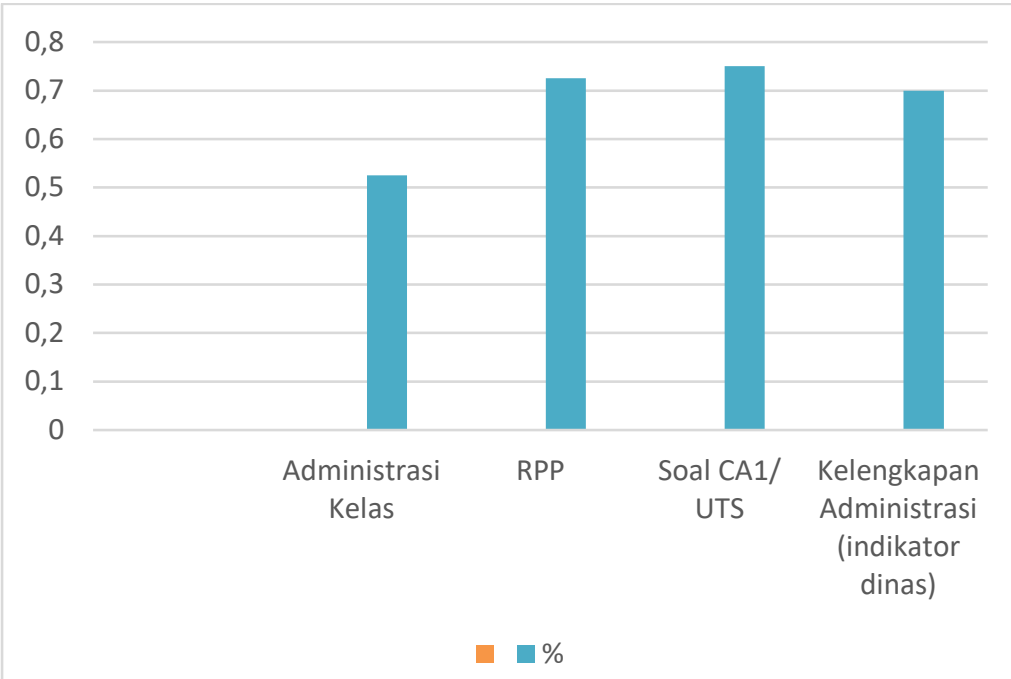

Gambar 2. Grafik Program Kinerja Guru Periode Juli-September 2021

\section{d. Refleksi}

Dalam pelaksanaan kegiatan belajar mengajar diperoleh informasi dari hasil pengamatan sebagai berikut:

1) Kepala Sekolah kurang memotivasi guru secara maksimal

2) Kepala Sekolah harus lebih ketat dalam memonitoring guru

3) Guru tidak terpacu dalam melengkapi administrasi pribadi dan kelas.

4) Guru kurang bisa mengembangkan model pembelajaran dikelas

5) Guru menganggap ringan sehingga selalu menunda pekerjaan

6) Guru kurang kreatif dalam mengembangkan metode pembelajaran

Revisi Pelaksanaan kegiatan belajar mengajar pada siklus I ini masih terdapat kekurangan, sehingga perlu adanya revisi untuk dilakukan pada siklus berikutnya.

1. Kepala Sekolah harus menjadi teladan

2. Kepala sekolah harus lebih terampil dalam memberi motivasi kepada guru Kepala sekolah perlu tegas dan mensosialisasikan kembali tentang tupoksi guru agar guru lebih mengerti dan memahami tugasnya. Pemberian reward kepada guru yang aktif dan memberikan teguran serta sanksi kepada guru yang tidak mau mengikuti program.

3. Kepala Sekolah harus melakukan pendekatan secara persuasive kepada guru secara individual dengan perbincangan secara pertemanan

4. Kepala Sekolah melakukan monitoring secara ketat dengan system absensi manual dan digital serta pengumpulan program menggunakan dateline waktu agar guru ketika diberi tugas diharapkan ontome dalam pengumpulan programnya.

5. Kepala Sekolah melakukan rapat dan berdiskusi tentang reward dan panisment

\section{Siklus II ( Oktober - Desember )}

\section{a. Tahap Perencanaan}

Pada tahap ini peneliti mempersiapkan perangkat penelitian berupa lembar presensi kehadiran Dan lembar pengumpulan program guru secara ketat. Selain itu juga dipersiapkan lembar observasi. Penilaian sama dengan penilaian di siklus 1 hanya di siklus 2 ditambahkan dengan penilaian kinerja guru (PKG)

\section{b. Tahap Kegiatan dan Pelaksanaan}

Pelaksanaan kegiatan belajar mengajar untuk siklus II dilaksanakan pada bulan Oktober sampai Desember dengan 2021 di SDS Royal Wells Primary School dengan jumlah guru sebanyak 17 orang 
MANAJERIAL : Jurnal Inovasi Manajemen dan Supervisi Pendidikan

Vol. 1 No. 3 Desember 2021, p-2797-5592 | e-2797-5606

Tabel 7. Rekapitulasi Penilaian Absen Periode Oktober-September

\begin{tabular}{|c|c|c|c|c|c|}
\hline No & Bulan & $\begin{array}{c}\text { Jumlah } \\
\text { Kehadiran }\end{array}$ & Kehadiran & Absensi (\%) & Ket \\
\hline & Oktober & 342 & 338 & $99 \%$ & Offline \\
\hline & November & 360 & 360 & $100 \%$ & Offline \\
\hline & Desember & 324 & 324 & $100 \%$ & Offline \\
\hline & Total & 1026 & 1022 & $100 \%$ & \\
\hline
\end{tabular}

Tabel 8. Rekapitulasi Penilaian Program Guru Periode Oktober - Desember 2021

\begin{tabular}{|c|c|c|c|c|c|c|}
\hline \multirow{2}{*}{ No } & \multirow{2}{*}{ Penilaian } & \multirow{2}{*}{$\begin{array}{c}\text { Jumlah } \\
\text { Guru }\end{array}$} & \multicolumn{2}{|c|}{ Interval } & \multirow{2}{*}{$\begin{array}{c}\text { Siklus } \\
1\end{array}$} & \multirow{2}{*}{$\%$} \\
\hline & & & Tertinggi & Terendah & & \\
\hline 1 & Administrasi Kelas & 17 & 4 & 2 & 3,4 & $85 \%$ \\
\hline 2 & RPP & 17 & 4 & 2 & 3,8 & $95 \%$ \\
\hline 3 & Soal CA1/ UTS & 17 & 4 & 2 & 3,9 & $98 \%$ \\
\hline 4 & Kelengkapan Administrasi & 17 & 4 & 2 & 3,4 & $85 \%$ \\
\hline \multicolumn{5}{|c|}{ Total } & 14,5 & $91 \%$ \\
\hline
\end{tabular}

Tabel 9 Rekapitulasi Penilaian Absen, Program Guru dan Penilaian Kinerja Guru Periode Juli-Desember 2021

\begin{tabular}{|c|l|c|c|c|c|c|c|}
\hline \multirow{2}{*}{ No } & \multicolumn{1}{|c|}{ Penilaian } & $\begin{array}{c}\text { Jumlah } \\
\text { Guru }\end{array}$ & $\begin{array}{c}\text { Siklus } \\
1\end{array}$ & $\%$ & Siklus 2 & $\%$ & Progres \\
\hline 1 & Administrasi Kelas & 17 & 2,1 & $53 \%$ & 3,4 & $85 \%$ & $33 \%$ \\
\hline 2 & RPP & 17 & 2,9 & $73 \%$ & 3,8 & $95 \%$ & $23 \%$ \\
\hline 3 & Soal CA1/ UTS & 17 & 3 & $75 \%$ & 3,9 & $98 \%$ & $23 \%$ \\
\hline 4 & Kelengkapan Administrasi & 17 & 2,8 & $70 \%$ & 3,4 & $85 \%$ & $15 \%$ \\
\hline 5 & Absen & 17 & 3,6 & $90 \%$ & 3,9 & $97 \%$ & $7 \%$ \\
\hline 6 & PKG Total & 17 & 2,8 & $69 \%$ & 3,7 & $93 \%$ & $24 \%$ \\
\hline \multicolumn{2}{|c|}{} & 17,2 & $72 \%$ & 22,1 & $91 \%$ & $19 \%$ \\
\hline
\end{tabular}

\section{a. Pengamatan (observasi)}

Dilaksanakan bersamaan dengan pelaksanaan belajar mengajar. Sebagai pengamat adalah peneliti dibantu oleh seorang guru dan HRD dan Pengawas dari dinas.

Adapun data hasil penelitian pada siklus II adalah sebagai berikut:

A. Jumlah Absensi Guru dari 93\% menjadi 100\% ( absensi berdasarkan PJJ dan absensi manual dan offline ), hasil absensi dibantu dengan pihak HRD

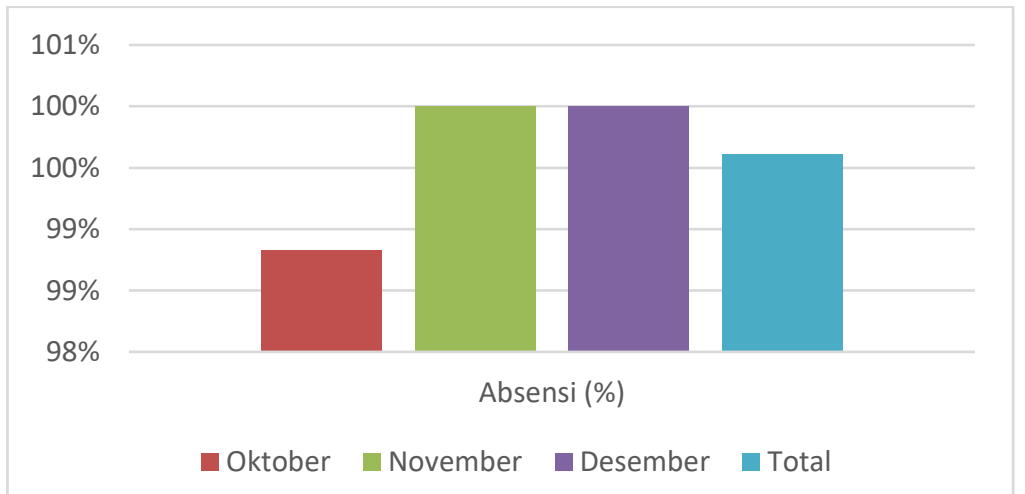

Gambar 3. Grafik Absensi Oktober - Desember 2021 
B. Pengumpulan program dari $68 \%$ menjadi 91\% (PJJ dikumpulkan melalui School Cordinator) dan pihak HRD sebagai bentuk prestasi guru

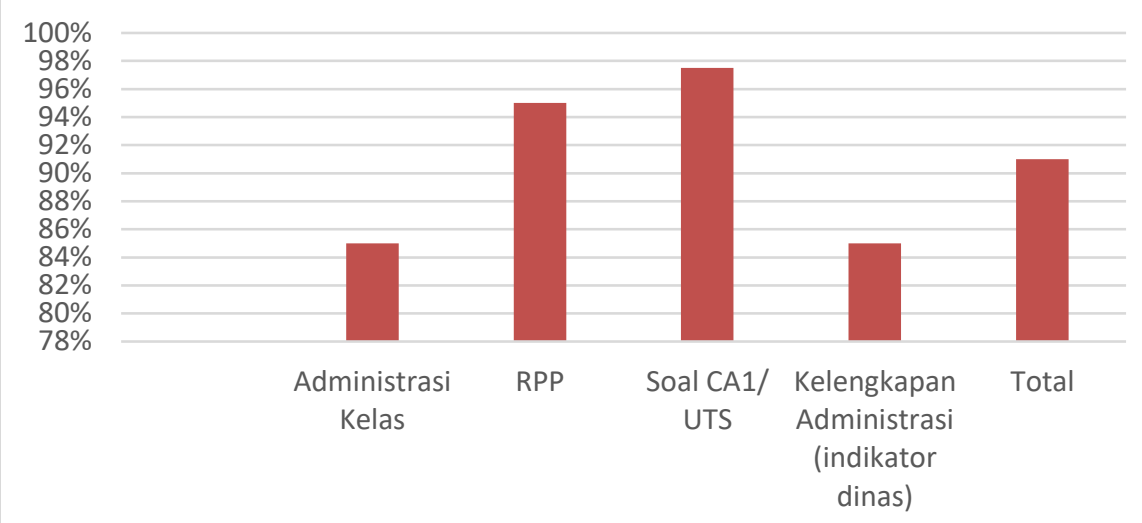

Gambar 4. Grafik Program Guru Bulan Oktober - Desember 2021

C. Program penilaian guru (PKG) dibantu pihak kedinasan sebagai bentuk monitoring dan supervise dari $72 \%$ menjadi $91 \%$ dengan kategori Baik

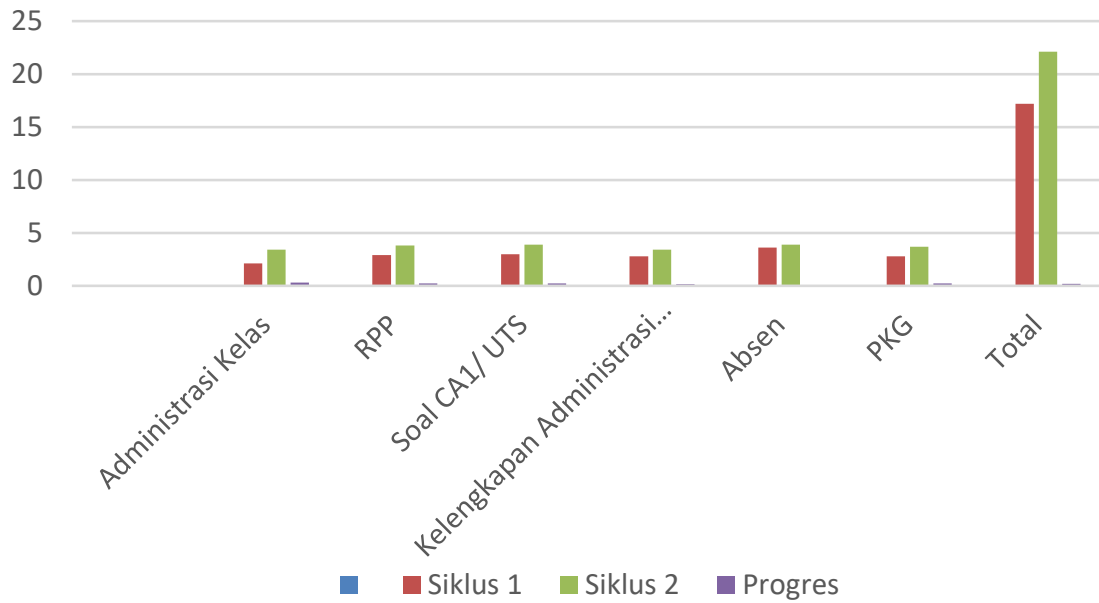

Gambar 5. Grafik Progres Siklus 1 Dan Siklus 2

\section{b. Refleksi}

Dalam pelaksanaan kegiatan belajar mengajar diperoleh informasi dari hasil pengamatan sebagai berikut:

1. Kepala Sekolah sudah memberikan motivasi kepada guru dengan menyampaikan tentang tugas tupoksi guru, tentang bentuk tanggungjawab guru, baik secara klasikal maupun pendekatan secara individual .

2. Kepala Sekolah telah memberikan arahan tentang cara mengajar yang baik, kreatif dan inovatif melalui rapat dan memberikan workshop yang diberikan baik secara kedinasan maupun workshop dengan lembaga lain.

3. Kepala Sekolah memfasilitasi Diklat ( Pendiidkan dan latihan) Penelitian Tindakan Kelas dengan mengundang narasumber agar guru lebih kreatif dan inovatif serta guru sudah mulai dapat berkembang untuk dapat menulis dan memeliti apa yang sudah dilakukan sebelunnya

4. Kepala Sekolah melakukan pendekatan psikologis kepada guru dengan cara memberikan motivasi dan memberi nasehat tentang tugas sebagai guru maupun sebagai pekerja.

5. Guru sudah mulai membuat kelengkapan administrasi pribadi dan kelas.

6. Guru sudah membuat metode pembelajaran secara kreatif dan inovatif.

7. Guru sudah bersemangat dalam mengajar 
c. Revisi Pelaksanaan kegiatan belajar mengajar pada siklus II ini, sudah berjalan denganbaik dan mendapatkan perubahan yang signifikan dalam kedisiplinan guru di dalam kelas berupa pelaksanaan administrasi dan pembelajaran.

\section{KESIMPULAN}

1. Pelaksanaan Profesionalitas Guru Dalam pelaksanaan kegiatan administrasi pribadi dan kelas, guru telah melaksanakan dengan baik, hal itu terbukti dengan adanya peningkatan prosentase kehadiran. Dari siklus pertama Absen kehadiran sebanyak 93\% meningkat ke siklus II sebanyak 100\%. Terdapat peningkatan sebanyak 7\% dan dalam rekap pengumpulan nilai dari $68 \%$ menjadi $91 \%$ terdapat peningkatan $19 \%$.

a. Rekapitulasi Progreas Absen Siklus 1 dan 2 terjadi kenaikan $6 \%$

Tabel 10. Rekapitulasi Penilaian absenpPeriode Juli - Desember 2021

\begin{tabular}{|c|c|c|c|c|c|c|}
\hline \multirow{2}{*}{ No } & Bulan & $\begin{array}{c}\text { Siklus } \\
1\end{array}$ & Absensi (\%) & Bulan & $\begin{array}{c}\text { Siklus } \\
2\end{array}$ & Absensi\%) \\
\hline & Juli & 180 & $100 \%$ & Oktober & 338 & $99 \%$ \\
\hline & Agustus & 364 & $92 \%$ & November & 360 & $100 \%$ \\
\hline & September & 362 & $91 \%$ & Desember & 324 & $100 \%$ \\
\hline Total & 906 & $93 \%$ & Total & 1022 & $100 \%$ \\
\hline
\end{tabular}

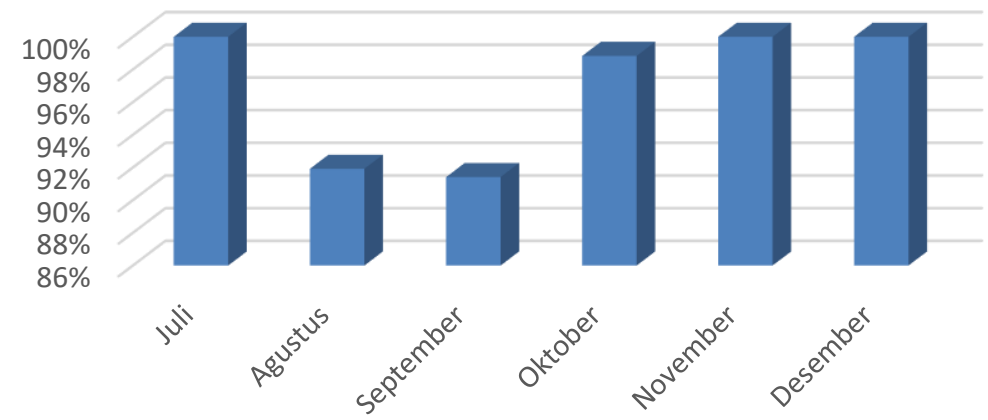

Gambar 6. Grafik Absen Siklus 1 Dan 2 Bulan Juli - Desember 2021

b. Rekapitulasi Progreas Program Kerja Guru Siklus1 dan 2 terjadi kenaikan $23 \%$ tanpa Penilaian Kinerja Guru

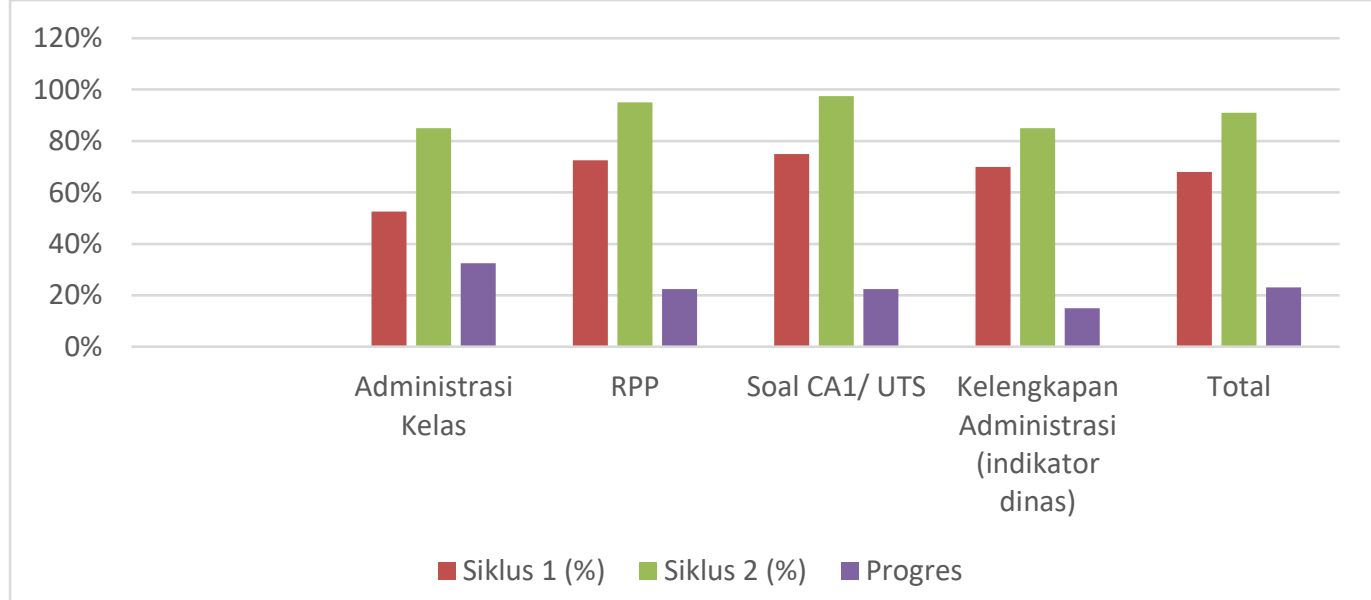

Gambar 7. Grafik Program Kinerja Guru Siklus 1 Dan 2 
c. Rekapitulasi Progreas Program Kerja Guru Siklus1 dan 2 terjadi kenaikan 19\% dengan Penilaian Kinerja Guru

Tabel 11

Rekapitulasi Penilaian Program Guru Periode Juli - Desember 2021

\begin{tabular}{|c|l|c|c|c|c|c|c|}
\hline No & \multicolumn{1}{|c|}{ Penilaian } & $\begin{array}{c}\text { Jumlah } \\
\text { Guru }\end{array}$ & $\begin{array}{c}\text { Siklus } \\
1\end{array}$ & $\%$ & $\begin{array}{c}\text { Siklus } \\
2\end{array}$ & $\%$ & Progres \\
\hline 1 & Administrasi Kelas & 17 & 2,1 & $53 \%$ & 3,4 & $85 \%$ & $33 \%$ \\
\hline 2 & RPP & 17 & 2,9 & $73 \%$ & 3,8 & $95 \%$ & $23 \%$ \\
\hline 3 & Soal CA1/ UTS & 17 & 3 & $75 \%$ & 3,9 & $98 \%$ & $23 \%$ \\
\hline & $\begin{array}{l}\text { Kelengkapan Administrasi } \\
\text { (indikator dinas) }\end{array}$ & 17 & 2,8 & $70 \%$ & 3,4 & $85 \%$ & $15 \%$ \\
\hline \multicolumn{2}{|c|}{ Total } & 10,8 & $68 \%$ & 14,5 & $91 \%$ & $23 \%$ \\
\hline
\end{tabular}

Tabel 12 Rekapitulasi Penilaian Program Guru dan Penilaian Kinerja GuruPeriode Juli - Desember 2021

\begin{tabular}{|c|l|c|c|c|c|c|c|}
\hline No & \multicolumn{1}{|c|}{ Penilaian } & $\begin{array}{c}\text { Jumlah } \\
\text { Guru }\end{array}$ & $\begin{array}{c}\text { Siklus } \\
1\end{array}$ & $\%$ & $\begin{array}{c}\text { Siklus } \\
2\end{array}$ & $\%$ & Progres \\
\hline 1 & Administrasi Kelas & 17 & 2,1 & $53 \%$ & 3,4 & $85 \%$ & $33 \%$ \\
\hline 2 & RPP & 17 & 2,9 & $73 \%$ & 3,8 & $95 \%$ & $23 \%$ \\
\hline 3 & Soal CA1/ UTS & 17 & 3 & $75 \%$ & 3,9 & $98 \%$ & $23 \%$ \\
\hline $\begin{array}{l}\text { Kelengkapan Administrasi } \\
\text { (indikator dinas) }\end{array}$ & 17 & 2,8 & $70 \%$ & 3,4 & $85 \%$ & $15 \%$ \\
\hline 5 & Absen & 17 & 3,6 & $90 \%$ & 3,9 & $97 \%$ & $7 \%$ \\
\hline 6 & PKG & 17 & 2,8 & $69 \%$ & 3,7 & $93 \%$ & $24 \%$ \\
\hline & \multicolumn{2}{|c|}{ Total } & 17,2 & $72 \%$ & 22,1 & $91 \%$ & $19 \%$ \\
\hline
\end{tabular}

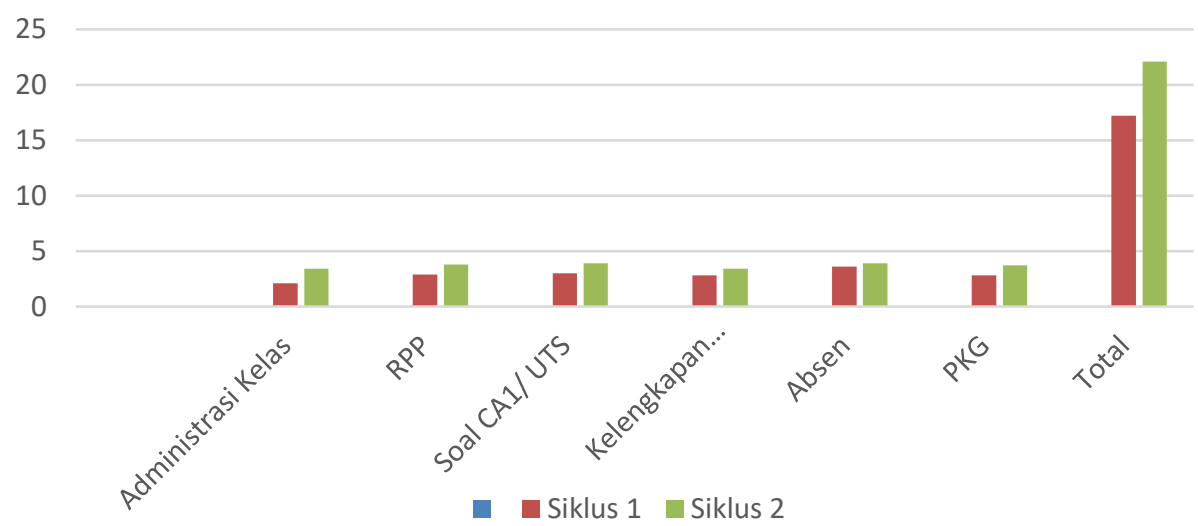

Gambar 8. Grafik rekapitullasi peogram kerja guru siklus 1 dan 2 Bulan juli desember 2021

2. Berdasarkan hasildata dapat disimpulkan bahwa motivasi kerja guru meningkat dan menghasilkan prestasi yang lebih baik

3. Program kerja kepala Sekolah untuk peningkatan kinerja guru tersampaikan dengan baik sehingga guru sudah mulai bekerja secara maksimal, bersemangat, kreatif dan inovatif.

4. Profesionalitas Guru Berdasarkan analisis data yang diperoleh dari data guru, telah terbukti guru sudah mulai aktif dalam membuat administrasi pribadi tepat waktu dan pengelolaan 
kelas dan inovasi pembelajaran sudah bervariasi.

\section{KESIMPULAN}

Berdasarkan hasil penelitian yang terurai, kami dapat menyimpulkan bahwa: Kepemimpinan memainkan peran penting dalam lembaga sekolah, dan harus memiliki strategi dengan membuat tujuan, merencanakan, mengorganisasikan, menggerakan, dan mengendalikan seluruh sumber daya yang dimiliki, sehingga tujuan akan tercapai secara efektif, efisien dikarenakan memiliki kerja tim yang solid dan kompak. Oleh sebab itu pemimpin dituntut untuk selalu menciptakan kondisi yang memuaskan mitra kerjanya dalam bekerja, sehingga diperoleh rekan kerja yang tidak hanya mampu bekerja tetapi juga bersedia bekerja untuk mencapai tujuan di masa depan maka dari itu Peran Kepala Sekolah dalam meningkatkan mutu pendidikan sangatlah penting. Kepala Sekolah menjadi ujung tombak dalam meningkatkan kinerja guru. Kepala Sekolah harus memilki program yang jelas dan tepat sehingga ketika menjalankan kepemimpinannya, mengetahui apa yang akan dan ingin dicapai. Kejelasan program menjadi hal penting untuk pondasi jalannya pendidikan di sekolah yang beliau pimpin sehingga diperlukan gaya kepemimpinan yang sesuai denga kulture dari tempat bekerja. Kepemimpinan Transformasi melengkapi peran kepemimpinan Kepala Sekolah, dimana pemimpin memiliki visi, strategi dan menjadi teladan bagi timnya, dan pemimpin transformasi akan berusaha memberikan semangat dan teladan, yang akan menimbulkan semangat dan kinerja para pengikut yang tinggi dalam melaksanakan program program sekolah sedangkan reward menjadi bonus tambahan untuk peningkatan kerja tim yang solid yaitu guru sebagai pelaksana program.

Guru sebagai pelaksana program merupakan orang penting dalam mentransfer ilmu ke anak didik, maka kinerja mereka harus meningkat agar hasil yang didapatkan mancapai hasil maksimal sesuai dengan tujuan. Profesionlitas guru yang rendah bisa ditingkatkan dengan menerapkan motivasi pada guru. Sehinga terjadi peningkatanpersentasi dari . Dari siklus pertama absensi sebanyak 93\% meningkat ke siklus II sebanyak $100 \%$, jadi terdapat peningkatan sebanyak $7 \%$ dan dalam pengumpulan program dari $68 \%$ menjadi $91 \%$ terdapat peningkatan 23\%. Demikina juga ketika Kepala Sekolah menambahkan penilaian kinerja guru terjadi peningkatan 19\%. Jadi dapat disimpulkan bahwa terjadi peningkatan yang signifikan terhadap kinerja guru di SD Royal Wells Primary School. Guru merupakan pendidik yang professional, mereka akan berkembang dengan pesat ketika pemimpinnya memberi peluang, memberi fasilitas, memotivasi , memberi pembinaan, dan membebaskan dalam berkreasi serta memberikan reward dan panisment yang jelas.

Perkembangan pendidikan akan berhasil ketika Kepala sekolah sebagai pemimpin, guru sebagai pelaksana, serta yayasan sebagai supporting berkolaborasi dengan baik akan menghasilkan sekolah yang berkualitas dan bermutu dan dicintai oleh masyarakat konsumen.

\section{DAFTAR PUSTAKA}

Hadis, Abdul dan B, Nurhayati. (2010). Manajemen Mutu Pendidikan. Alfabeta: Bandung.

Kartini Kartono. (1983). Pemimpin dan Kepemimpinan. Jakarta : CV RAJAWALI

Makawimbang, Jerry. (2011). Supervisi dan Peningkatan Mutu Pendidikan. Bandung: Alfabeta. Mar'at. (1980). Pemimpin dan kepemimpinan. Bandung : Ghalia Indonesia

Nazir. Muhammad. (2003). Metode Penelitian. Jakarta: Ghalia Indonesia

Peraturan Menteri Pendidikan Nasional No.63 tahun 2009 Pasal (1) ayat (1)

Peraturan Pemerintah No.32 Tahun 2013 Tentang Standar Nasional Pendidikan (SNP).

Riyono, Bagus. (1999). Kepemimpinan Transformasional. Buletin Psikologi Tahun VII. No.1.

Fakultas Psikologi UGM.

Sistem Pendidikan Nasional. Kemendikbud Tahun 2014.

Sugiyono. (2016). Metode Penelitian Pendidikan Pendek Kamus Besar Bahasa Indonesia.

Kemendiknas. Pusat Bahasa

Umiarso, dan Imam Gojali. (2010). Manajemen Mutu Sekolah di Era Otonomi Pendidikan. 
Jogjakarta: IRCiSoD.

Wirawan. 2014. Kepemimpinan, Jakarta; PT Raja Grafindo Persada 